\title{
ІНЖЕНЕРНІ НАУКИ
}

УДК 697.7

https://doi.org/10.35546/kntu2078-4481.2020.1.1.1

О.В. АНДРОНОВА

Херсонський національний технічний університет ORCID: 0000-0001-9597-8068

B.В. КУРАК

Херсонський національний технічний університет ORCID: 0000-0002-4303-5671

К.І. СОКОЛ

Приватне підприємство «СВІТОСИЛА» ORCID: 0000-0001-5155-7202

\section{ТЕПЛОВИЙ РЕЖИМ БУДІВЛІ З ПАСИВНОЮ СИСТЕМОЮ ОПАЛЕННЯ}

Одним з найбільших споживачів енергії для багатьох країн світу є житлово-комунальний сектор, тому енергозбереження та використання відновлюваних джерел енергії в даному секторі дозволяють досягти суттєвої економії енергоресурсів в масштабах краӥни. Реалізація потенціалу енергозбереження ускладнюється великим різноманіттям існуючого житлового фонду, щуо вимагає індивідуального підходу при вирішенні задач енергозбереження та енергозабезпечення будівель. Корисним для України є досвід Швеиії, Фінляндіi, Германії, США у використанні пасивних систем сонячного опалення, які при правильному проектуванні мають ккд до 60\% і покривають понад 50\% навантаження опалення. Недостатня кількість публікаџій щодо ефективності та впровадження таких систем для кліматичних умов Украӥни викликала необхідність проведення моделювання теплового режиму будівлі з пасивною системою сонячного опалення для виявлення можливостей покриття енергопотреб.

В програмному середовищі MatLab/Simulink створена модель будівлі, яка дозволяє визначити зміни температури огороджувальних конструкиій та внутрішнього повітря при змінних параметрах оточуючого середовища, а саме сонячній радіації, температур зовнішнього повітря та трунту. Надходження сонячної радіації на зовнішні огороджувальні конструкиії будівлі обчислено для кожної години доби протягом року для кліматичних умов м. Херсона. На основі результатів моделювання визначено амплітуди коливань температури внутрішнього повітря, затримки у надходженні тепла у будівлю, енергопотреби та тривалість періодів опалення й охолодження.

Проведено порівняння теплових режимів трьох варіантів одноквартирної будівлі: без пасивноі системи сонячного опалення, зі стіною Тромбе та зі стіною Тромбе й ролетами для затінення. Визначено, що застосування стіни Тромбе призводить до зменшення на 76,9\% енергопотреби на опалення, однак сприяє значному перегріву приміщення у теплий період року, а, отже, $i$ підвищенню енергопотреби на охолодження в 3,4 рази. Показано, щзо скоротити енергопотреби як на опалення, так $i$ на охолодження дозволяє впровадження стіни Тромбе із затіненням в літній період ролетами.

Ключові слова: стіна Тромбе, енергопотреба, опалення, охолодження, огороджувальні конструкиії будівлі.

Е.В. АНДРОНОВА

Херсонский национальный технический университет ORCID: 0000-0001-9597-8068

В.В. КУРАК

Херсонский национальный технический университет ORCID: 0000-0002-4303-5671

К.И. СОКОЛ

Частное предприятие «СВЕТОСИЛА» ORCID: 0000-0001-5155-7202

\section{ТЕПЛОВОЙ РЕЖИМ ЗДАНИЯ С ПАССИВНОЙ СИСТЕМОЙ ОТОПЛЕНИЯ}

Одним из наибольших потребителей тепловой энергии для многих стран мира является жилищно-коммунальный сектор, поэтому энергосбережение и использование возобновляемых источников энергии в данном секторе позволяют достичь существенной экономии энергоресурсов в 
масштабах страны. Реализация потенцииала энергосбережения усложняется большим разнообразием существующего жилищного фонда, что требует индивидуального подхода при решении задач энергосбережения и энергообеспечения зданий. Полезным для Украины является опыт Швеции, Финляндии, Германии, США в использовании пассивных систем солнечного отопления, которые при правильном проектировании имеют кпд до 60\% и покрывают свыше 50\% нагрузки отопления. Недостаточное количество публикащий, касающихся эффективности и внедрения таких систем для климатических условий Украины вызвало необходимость проведения моделирования теплового режима здания с пассивной системой солнечного отопления для выявления возможностей покрытия энергопотребностей.

В программной среде MatLab/Simulink создана модель здания, которая позволяет определять изменения температуры ограждающих конструкций и воздуха внутри здания при переменных параметрах окружающей среды, а именно солнечной радиации, температур наружного воздуха и грунта. Поступление солнечной радиачии на внешние ограждающие конструкиии здания рассчитань для каждого часа суток на протяжении года для климатических условий г. Херсон. На основе результатов моделирования определены амплитуды колебаний температуры внутреннего воздуха, задержки в поступлении тепла в здание, энергопотребности та продолжительности периодов отопления и охлаждения.

Проведено сравнение тепловых режимов трех вариантов одноквартирного здания: без пассивной системы солнечного отопления, со стеной Тромбе и со стеной Тромбе и затеняющими роллетами. Выяснено, что использование стень Тромбе приводит к уменьшению на 76,9\% энергопотребности отопления, однако способствует значительному перегреву помещения в тепльй период года, и, таким образом, к возрастанию энергопотребности охлаждения в 3,4 раза. Показано, что сократить энергопотребности как отопления, так и охлаждения позволяет внедрение стень Тромбе с роллетами, используемьми в тепльй период года.

Ключевые слова: стена Тромбе, энергопотребность, отопление, охлаждение, ограждающие конструкичи здания.

E.V. ANDRONOVA Kherson National Technical University ORCID: 0000-0001-9597-8068

V.V. KURAK

Kherson National Technical University ORCID: 0000-0002-4303-5671

K.I. SOKOL

Private enterprise «SVITOSILA» ORCID: 0000-0001-5155-7202

\section{THERMAL MODE OF BUILDING WITH A PASSIVE HEATING SYSTEM}

One of the largest energy consumers for many countries over the world is the housing and communal sector, so energy saving and the use of renewable energy in this sector make it possible to achieve significant energy savings. The realization of the energy saving potential is complicated by the great diversity of the existing housing stock, which requires an individual approach in solving the problems of energy saving and energy supply of buildings. The experience of Sweden, Finland, Germany and the USA in the use of passive solar heating systems is useful for Ukraine. These systems, when properly designed, have an efficiency of up to $60 \%$ and cover more than $50 \%$ of the heating load. However, the insufficient number of publications on the efficiency and implementation of passive solar heating systems for the climatic conditions of Ukraine caused the need to simulate the thermal mode of the building with such system to determine the possibility of energy needs covering.

A building model has been created using the MatLab/Simulink software. This model allows determining temperatures of enclosure structures and indoor air in connection with variable environmental parameters, such as solar radiation, ambient air and soil temperatures. The solar irradiation to the building's exterior enclosure structures was calculated for each hour of the day during the year for Kherson's climatic conditions. Based on the simulation results, the indoor air temperature oscillations amplitudes, time displacement in heat input to the building, energy needs and duration of heating and cooling periods are determined.

The thermal modes of the three residential building variants are compared: without a passive solar heating system, with the Trombe wall and the Trombe wall and shading shutters. It has been determined that using of the Trombe wall reduces heating energy need of $76.9 \%$, but leads to a significant room overheating during the warm period of the year and, consequently, to increasing of cooling energy need by 3.4 times. It is shown that using of the Trombe wall with shading shutters leads to reducing the energy demand for both heating and cooling. 
Keywords: Trombe wall, energy need, heating, cooling, enclosure structures.

\section{Постановка проблеми}

Житлово-комунальне господарство на сьогодні $є$ одним 3 найбільших енергоспоживачів: на забезпечення комфортних умов в приміщенні витрачається близько $40 \%$ від загальної кількості первинної енергії $[1,2]$. Тому питанням зниження енергопотреби будівель та підвищення іх енергоефективності приділяється пильна увага як на стадії експлуатації існуючих будівель, так і при проектуванні нових.

Одним з напрямків підвищення енергетичної ефективності, поширеним у європейських країнах та США, є впровадження пасивних систем опалення. Як показують вимірювання та моделювання, пасивні системи дозволяють економити від 30 до 70\% теплової енергії [3-5]. На величину економії суттєво впливають вид пасивної системи опалення, кліматичні дані місця розташування будівлі, іiі об’ємно-планувальні рішення, рівень теплозахисту та ін. Така багатофакторність потребує попереднього визначення конструктивних параметрів та енергетичних характеристик пасивних систем для конкретних будівель, що розташовані в певних кліматичних умовах.

\section{Аналіз останніх досліджень і публікацій}

У роботах $[5,6]$ представлено методи оцінки річної ефективності пасивних систем опалення, що побудовані на залежностях, отриманих на основі результатів численних моделювань для кліматичних умов США. Для розрахунку помісячного вироблення енергії пасивною системою опалення використовуються такі вхідні параметри, як середньомісячні значення надходження сонячної радіації, коефіцієнт теплопередачі та теплоємність огороджувальних конструкцій будівлі. Представлені методи дають оцінку річного вироблення тепла пасивною системою, але не надають інформації щодо динаміки процесу.

Динамічне моделювання теплового режиму будівлі дозволяє досліджувати температурні процеси всередині приміщення залежно від змін у режимах експлуатації та зовнішніх кліматичних факторів [7, 8]. В роботі [9] на основі моделі будівлі із пасивною системою опалення досліджувався вплив прозорої теплоізоляції на енергетичну ефективність стіни Тромбе для кліматичних умов Чехії, однак при моделюванні не враховувались внутрішні теплонадходження та наявність вікон у будівлі. Моделі $[2,10]$ побудовано для визначення оптимальних конструктивних параметрів пасивних систем опалення при роботі в кліматичних умовах Сербії та Кіпру. В той же час, в літературі не приділено належної уваги моделюванню роботи, проектуванню та використанню таких систем для кліматичних умов України.

\section{Формулювання мети дослідження}

Метою даної роботи $є$ моделювання теплового режиму будівлі з пасивною системою опалення для кліматичних умов півдня України.

\section{Викладення основного матеріалу дослідження}

Модель будівлі, побудованої в MatLab/Simulink, складається 3 підсистем, що описують огороджувальні конструкції, які орієнтовані за відповідними сторонами горизонту (рис. 1). Зміна параметрів оточуючого середовища задається блоками температури зовнішнього повітря, температури грунту [11] та блоками розподілу сонячної радіації. Для проведення симуляції теплового режиму будівлі надходження сонячної радіації визначалось для кожної години кожного дня року за методикою [5] 3 використанням кліматичних даних [12] для всіх орієнтацій огороджувальних конструкцій:

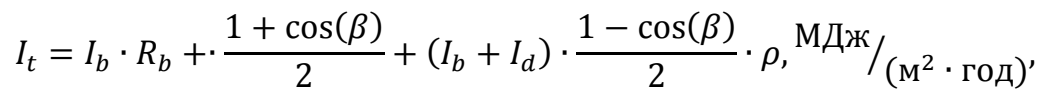

де $\quad I_{b}$ i $I_{d}-$ погодинні значення прямої й розсіяної складових сонячної радіації на горизонтальній поверхні, МДж/(м²·год);

$\rho$ - альбедо;

$\beta$ - кут нахилу приймаючої поверхні до горизонту, град;

$R_{b}$ - коефіцієнт перерахунку прямої сонячної радіації з горизонтальної поверхні на нахилену.

У підсистемах огороджувальних конструкцій враховано сумарну теплопередачу трансмісією та теплообмін випромінюванням між конструкціями та оточуючим середовищем, а саме нагрівання за рахунок надходження сонячної радіації та радіаційні тепловтрати в оточуюче середовище. Стіна Тромбе (рис. 2) складається з світлопрозорої ізоляції (однокамерний склопакет з ПВХ профілем) та пофарбованої у чорний колір бетонної стіни 3 розташованим між ними повітряним прошарком. Як склопакет, так i бетонну конструкцію представлено блоками теплопровідності з розташованою посередині термальною масою. Враховано теплообмін між склопакетом та стіною у повітряному прошарку трьома паралельними шляхами, що представлено блоками теплопередачі кондуктивністю, конвекцією та випромінюванням. 3 урахуванням коефіцієнту пропускання світлопрозорого покриття перерозподілено потік сонячного 
випромінювання між поверхнями бетонної стіни та засклення. 3 внутрішньої поверхні стіни тепло передається до термальної маси внутрішніх огороджувальних конструкцій та повітря конвекцією та випромінюванням.

3 урахуванням впливу зовнішніх змінних факторів, таких як сонячна радіація, температура зовнішнього повітря та температура грунту, модель дозволяє отримати температури огороджувальних конструкцій та повітря всередині приміщення, на основі яких визначались затримка у часі між моментом досягнення максимальної температури поверхнею стіни Тромбе та моментом досягнення максимальної температури повітря всередині приміщення; амплітуда добових коливань температури всередині будівлі та енергопотреби на опалення та охолодження будівлі.

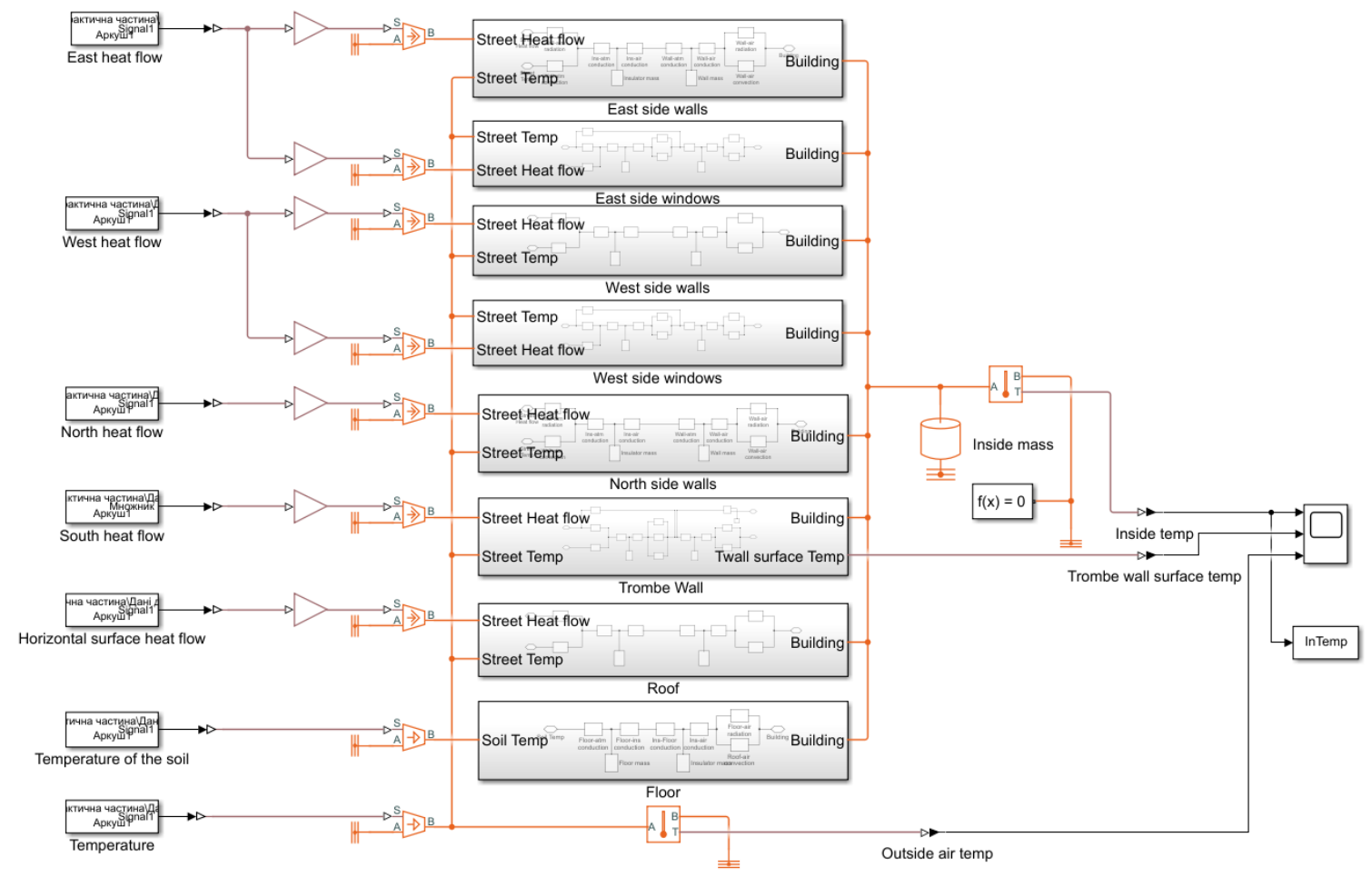

Рис. 1. Модель будівлі в MatLab/Simulink

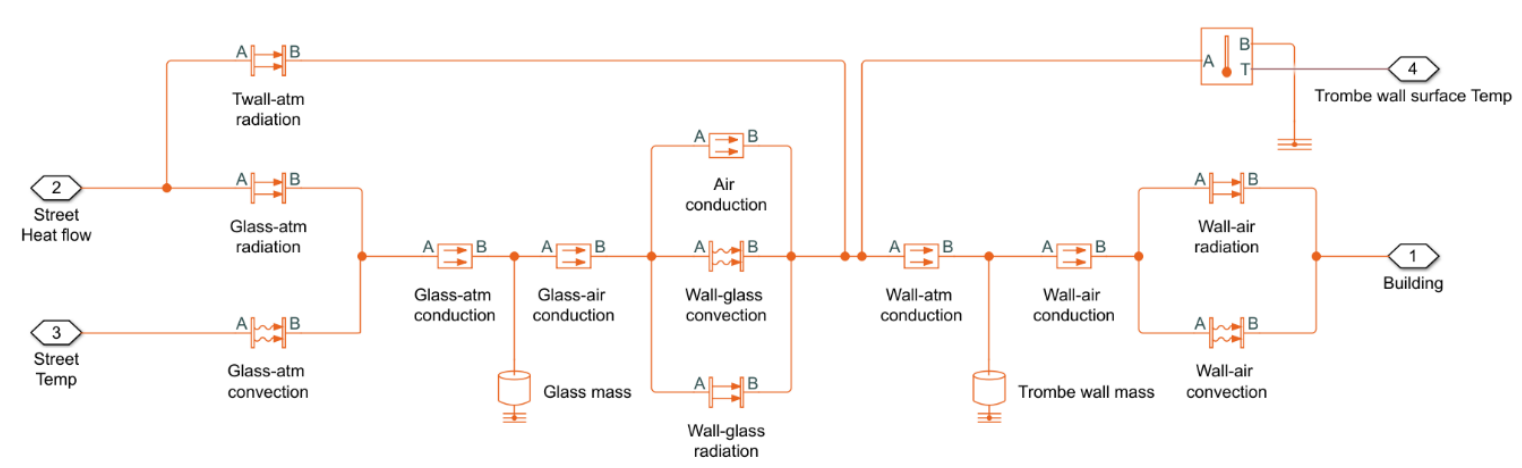

Рис. 2. Модель стіни Тромбе

Енергопотреба на опалення будівлі:

$$
E_{h}=\frac{H_{t r}}{3600} \sum\left(T_{h}-T_{i n}\right) \cdot\left(t_{i}-t_{i-1}\right), \text { Вт } \cdot \text { год, }
$$

де

$T_{h}$ - задана температура зони будівлі для опалення, К;

$T_{\text {in }}$ - температура всередині будівлі, К;

$t_{i}$ - час, у який температура всередині будівлі має значення $T_{i n}, \mathrm{c}$;

$H_{t r}$ - загальний коефіцієнт теплопередачі трансмісією, Вт/К: 


$$
H_{t r}=H_{D}+H_{g}, \mathrm{BT} / \mathrm{K}^{\prime}
$$

де $H_{D}-$ безпосередній узагальнений коефіцієнт теплопередачі трансмісією до зовнішнього середовища, Вт/К;

$H_{g}$ - стаціонарний коефіцієнт теплопередачі трансмісією до грунту.

$$
H_{D}=\sum A_{i} \cdot U_{i}, \mathrm{BT} / \mathrm{K}^{\prime}
$$

де $\quad A_{i}-$ площа і-го елемента будівлі, $\mathbf{m}^{2}$;

$U_{i}$ - приведений коефіцієнт теплопередачі і-го елемента оболонки будівлі, Вт/(м²·К) [11].

Енергопотреба на охолодження будівлі:

$$
E_{c}=\frac{H_{t r}}{3600} \sum\left(T_{i n}-T_{c}\right) \cdot\left(t_{i}-t_{i-1}\right), \text { Вт } \cdot \text { год, }
$$

де

$T_{c}$ - задана температура зони будівлі для охолодження, К.

Визначення теплових режимів спочатку проводилось для будівлі без пасивної системи опалення. Для моделювання обрано двоповерхову будівлю розміром $10 \times 6 \times 6$ м, що розташована у м. Херсоні. Площа південного фасаду становить $60 \mathrm{~m}^{2}$; на південному, східному та західному фасадах розташовано вісімнадцять вікон $\left(4 \mathrm{M}_{1}-16-4 \mathrm{~K}\right)$ загальною площею $34,44 \mathrm{~m}^{2}$. Опори теплопередачі огороджувальних конструкцій відповідають нормативним вимогам. Згідно результатів моделювання енергопотреба на опалення становить 6696,48 кВт·год, на охолодження 2074,92 кВт·год, а питома енергопотреба будівлі складає 88,1 кВт·год/м², що відповідає класу енергоефективності В. Тривалість опалювального періоду становить $n_{h}=185$ діб, а періоду охолодження $n_{c}=122$ доби. Без додаткових систем опалення та охолодження влітку температура в будівлі сягає значень 306 К, а взимку знижується до 276 К.

Промодельовано тепловий режим цієї будівлі з пасивною системою опалення - стіною Тромбе на південному фасаді. Конструктивні параметри стіни Тромбе обиралися наступними: товщина повітряного прошарку $5 \mathrm{~cm}$, бетонної стіни $15 \mathrm{~cm}$, світлопрозора ізоляція $4 \mathrm{M}_{1}-8-4 \mathrm{M}_{1}$, площа $60 \mathrm{~m}^{2}$. Результати моделювання представлено в табл.1 та на рис. 3.

Тепловий режим будівлі

\begin{tabular}{|l|c|c|c|}
\hline \multicolumn{1}{|c|}{ Параметри } & Без стіни Тромбе & Зі стіною Тромбе & $\begin{array}{c}\text { Зі стіною Тромбе та } \\
\text { ролетами }\end{array}$ \\
\hline$E_{h}$, кВт·год & 6696,48 & 1543,74 & 1552,11 \\
\hline$E_{c}$, кВт·год & 2074,92 & 6963,58 & 320,36 \\
\hline$E_{h}+E_{c}$, кВт·год & 8771,40 & 8507,32 & 1872,47 \\
\hline$n_{h}$, діб & 185 & 110 & 110 \\
\hline$n_{c}$, діб & 122 & 203 & 64 \\
\hline
\end{tabular}

Аналіз даних табл. 1 дозволяє зробити висновок, що використання пасивної системи дає можливість зменшити витрати енергоресурсів на опалення на 5152,74 кВт·год, але одночасно збільшує витрати на охолодження на 4888,66 кВт·год, що майже нівелює позитивний ефект: загальні енергопотреби будівлі знижуються лише на $3 \%$.

Моделювання теплового режиму будівлі зі стіною Тромбе дозволило також визначити такі параметри пасивної системи опалення, як затримка у часі надходження тепла у будівлю та амплітуда добових коливань температури внутрішнього повітря. Результати для характерних діб різних періодів року представлені на рис. 4 та в табл. 2. 


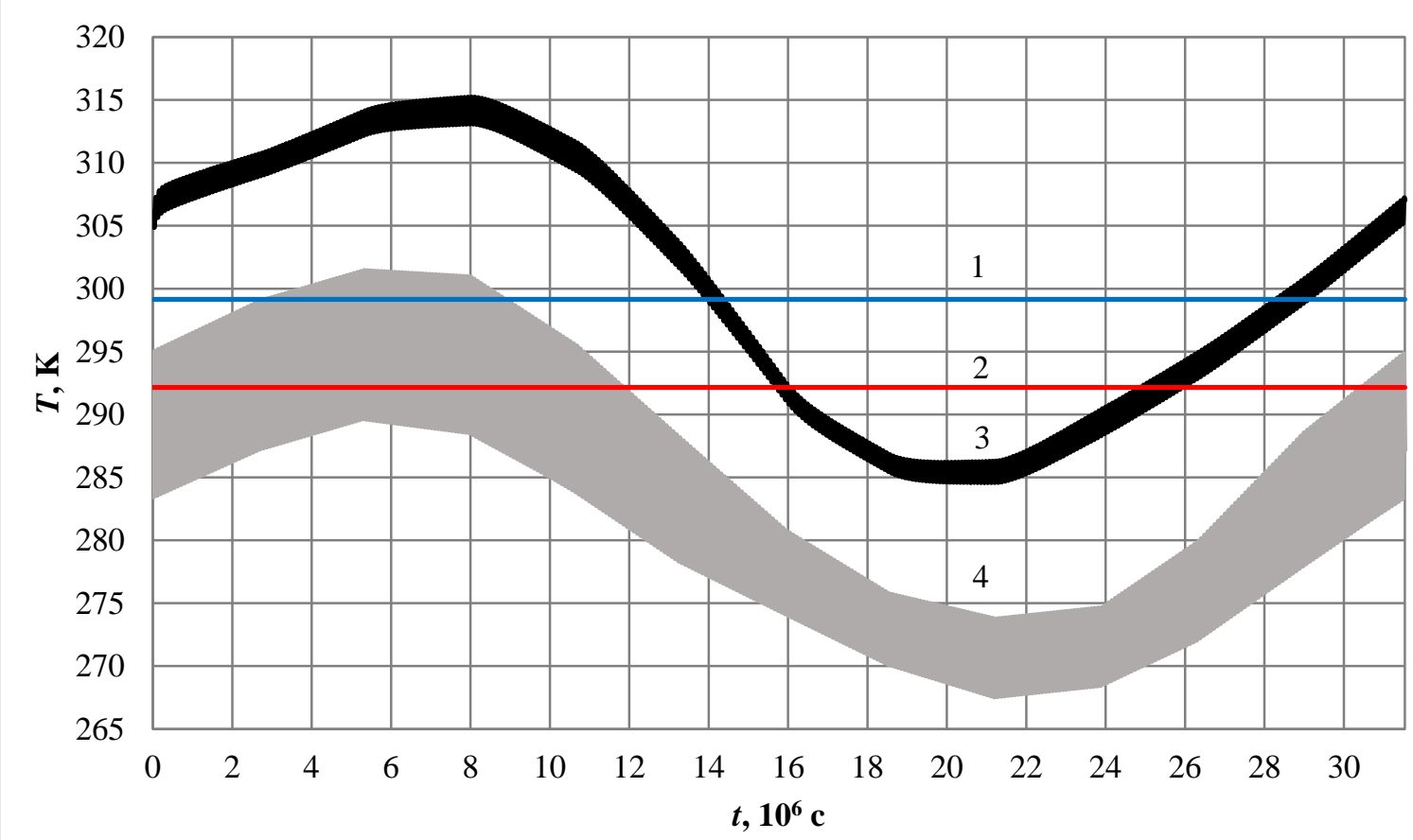

Рис. 3. Річний розподіл температур всередині будівлі зі стіною Тромбе:

1 - межа увімкнення кондиціонування; 2 - межа увімкнення опалення; 3 - температура внутрішнього повітря; 4 - температура зовнішнього повітря
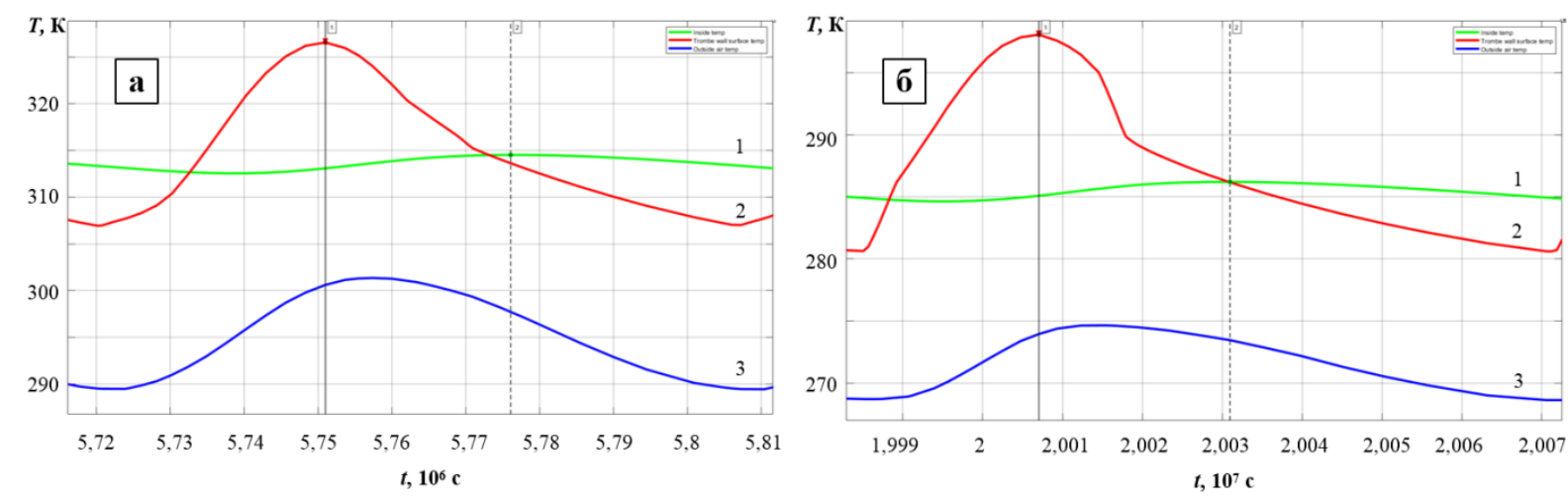

Рис. 4. Затримка у часі надходження тепла в будівлю зі стіною Тромбе

в літній (а) та зимовий (б) період:

1 - температура внутрішнього повітря; 2 - температура стіни Тромбе;

3 - температура зовнішнього повітря

Таблиця 2

Температурний режим в приміщенні

\begin{tabular}{|c|c|c|c|}
\hline Сезон & Затримка, год:хв & Амплітуда, К & Середня температура, К \\
\hline \multicolumn{4}{|c|}{ Зі стіною Тромбе } \\
\hline Літній & 6:58 & 1,98 & 313,53 \\
\hline Осінній & $6: 28$ & 1,94 & 303,47 \\
\hline Зимовий & 6:39 & 1,58 & 285,42 \\
\hline Весняний & 7:14 & 2,05 & 297,47 \\
\hline \multicolumn{4}{|c|}{ Зі стіною Тромбе та ролетами } \\
\hline Літній & 9:29 & 0,49 & 301,12 \\
\hline Осінній & 7:16 & 1,15 & 294,72 \\
\hline Зимовий & $6: 39$ & 1,58 & 285,42 \\
\hline Весняний & $7: 10$ & 1,39 & 294,06 \\
\hline
\end{tabular}


У будівлі, яку обладнано стіною Тромбе, затримка надходження тепла у приміщення в середньому становить 6 год 50 хв, а амплітуда коливань 1,9 К, що є вищим за нормоване значення 1,5 К, влітку спостерігається значний перегрів приміщення на 20,5 К, а взимку недогрів на 7,6 К. Для запобігання перегріву будівлі використовується затінення стіни Тромбе ролетами у теплий період року. Річний розподіл температур усередині будівлі з пасивною системою опалення при використанні ролет, показано на рис. 5 .

Додаткове використання затінення ролетами призвело до зменшення на 6643,22 кВт·год енергопотреб будівлі на охолодження в порівнянні з варіантом стіни Тромбе без ролет, а період охолодження скоротився на 139 діб (табл. 1). При цьому енергопотреби на опалення зросли всього на 8,37 кВт·год, що пов'язано 3 меншою кількістю теплової енергії, акумульованої стіною Тромбе. Як наслідок, загальні енергопотреби на опалення та охолодження знизилися в понад 4,5 рази. Крім того, зменшення в літній період надходження сонячної радіації на стіну Тромбе завдяки затіненню ролетами призвело до значного зниження перегріву (на 8 К) та амплітуди коливань температури всередині приміщення, при цьому також збільшилася часова затримка в надходженні тепла, що пов'язано 3 меншим температурним напором (табл. 2).

Отже, застосування пасивної системи на основі стіни Тромбе з затіненням ролетами в кліматичних умовах м. Херсона дозволяє зменшити енергопотребу будівлі на опалення на 76,8\%, на охолодження - на 84,6\%, а загальну енергопотребу - на 78,7\%, період опалення скорочується на $40 \%$, а період охолодження майже вдвічі. Будівля із пасивною системою опалення потребує менших потужностей традиційних джерел тепла та холоду для забезпечення комфортних умов в приміщенні. Питома енергопотреба скорочується до 30,6 кВт.год/ ${ }^{2}$, а клас енергетичної ефективності будівлі підвищується з В до А.

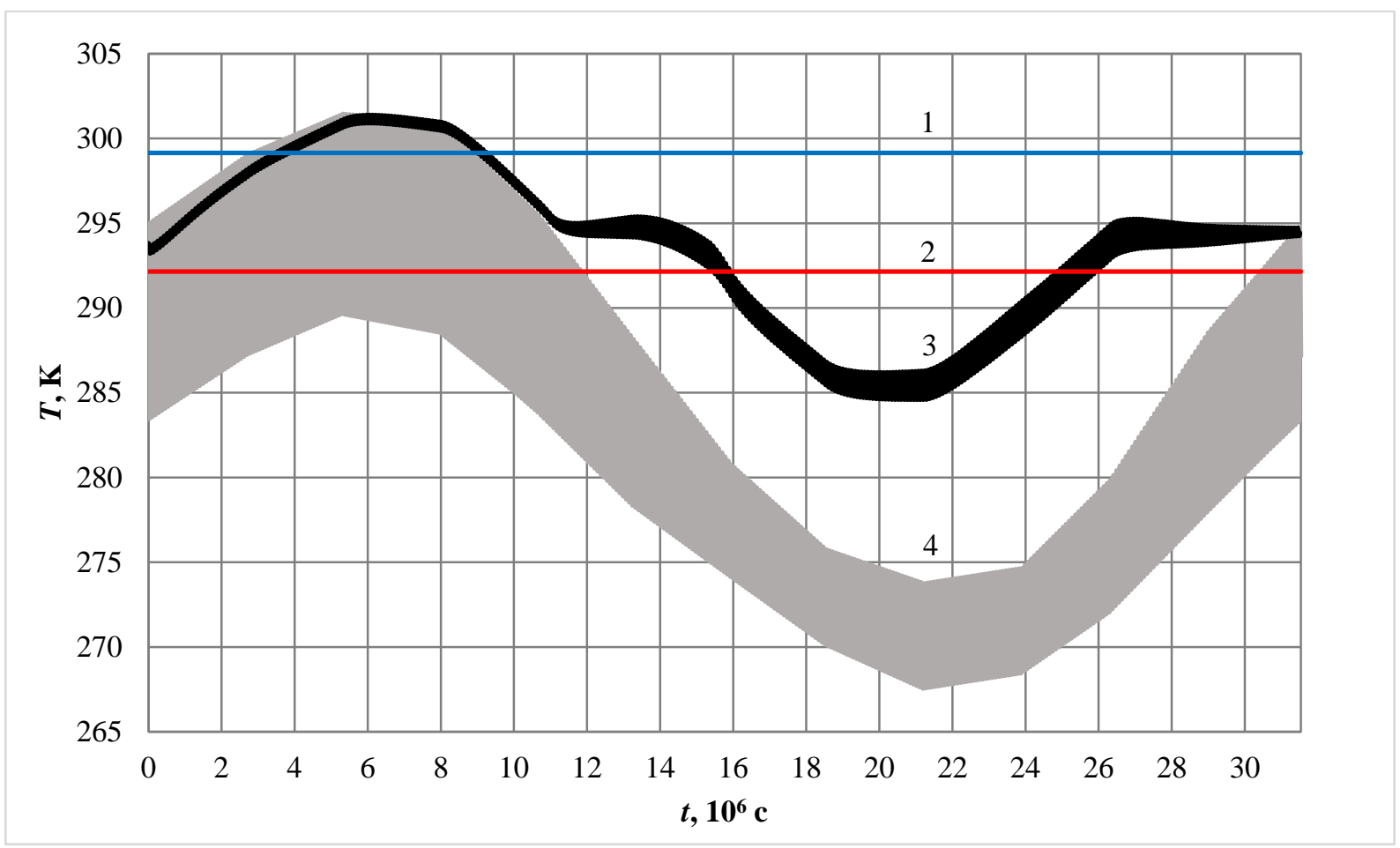

Рис. 5. Річний розподіл температур всередині будівлі

зі стіною Тромбе й затіненням ролетами:

1 - межа увімкнення кондиціонування; 2 - межа увімкнення опалення;

3 - температура внутрішнього повітря; 4 - температура зовнішнього повітря

\section{Висновки}

Моделювання теплового режиму будівлі в програмному середовищі MatLab/Simulink дозволило визначити температурний режим експлуатації будівлі, енергопотреби для опалення, охолодження та клас енергоефективності.

Порівняння результатів моделювання теплового режиму будівлі без пасивної системи опалення та зі стіною Тромбе, проведеного для кліматичних умов м. Херсона, показало, що впровадження пасивної системи дозволяє скоротити енергопотребу на опалення на 76,9\%, але при цьому спостерігається погіршення температурного режиму у літній період: температура внутрішнього повітря зростає з 306 К до 315 К, що викликає необхідність збільшення потужності системи охолодження та 
періоду іï роботи на 81 добу. Сумарна енергопотреба будівлі при цьому зменшується на 3 \%. Для зменшення перегріву будівлі у теплий період року необхідно застосовувати затінення південного фасаду ролетами. Це дозволяє знизити температуру внутрішнього повітря влітку до $301 \mathrm{~K}$, зменшити амплітуду iiі коливань та навантаження охолодження.

Впровадження стіни Тромбе з затіненням ролетами дає енергетичний виграш 78,7\%, скорочує періоди опалення та охолодження, підвищує клас енергоефективності будівлі. Отже, використання таких систем при реалізації проектів енергоефективних будівель в кліматичних умовах півдня України $є$ доцільним.

\section{Список використаної літератури}

1. Saleh Nasser Al-Saadi. Modeling and simulation of PCM-enhanced façade systems. PhD thesis. Boulder, Colorado, 2014. 472 p.

2. Djordjević A.V., Radosavljević J.M., Vukadinović A.V., Malenović Nikolić J.R., Bogdanović Protić I.S. Estimation of indoor temperature for a passive solar building with a combined passive solar system. Journal of Energy Engineering, 2017, no.143(4), pp. 04017008-1-10. DOI: 10.1061/(ASCE)EY.19437897.0000437.

3. Zhongting Hu, Wei He, Jie Ji, Shengyao Zhang. A review on the application of Trombe wall system in buildings. Renewable and Sustainable Energy Reviews, 2017, vol. 70(C), pp. 976-987. DOI: 10.1016/j.rser.2016.12.003.

4. Gupta N., Tiwari G.N. Review of passive heating/cooling systems of buildings. Energy Science and Engineering, 2016, no. 4(5), pp. 305-333. DOI: 10.1002/ese3.129.

5. Duffie J.A., Beckman W.A. Solar Engineering of Thermal Processes. Hoboken, John Wiley \& Sons, Inc., 2013. 910 p.

6. Balcomb J. D., McFarland R.D. A simple empirical method for estimating the performance of a passive solar heated building of the thermal storage wall type. Proc. of $2^{\text {nd }}$ National Passive Solar Conference. Philadelphia, PA, 1978, 13 p. (Preprint copy).

7. Стрижак П.А. Математическое моделирование теплового режима здания с учетом инсоляционных теплопоступлений / П.А. Стрижак, М.Н. Морозов // Известия Томского политехнического университета. Инжиниринг георесурсов. - 2015. - Т. 326, № 8. - С. 36-46.

8. Иссам А. Моделирование тепловых режимов эксплуатации зданий с использованием систем MatLab/ Simulink / А. Иссам // Известия ВУЗов. Северо-Кавказский регион. Технические науки. - 2009. - № 1. C. 95-99.

9. Matuska T. A simple Trombe wall: Comparison of different glazings. Proc. of 3rd ISES Congress Eurosan, Copenhagen, 2000, 6 p. (Preprint copy).

10. Özdenefe M., Atikol U., Rezaei M. Trombe wall size-determination based on economic and thermal comfort viability. Solar Energy, 2018, Vol.174, pp. 359-372. DOI: 10.1016/j.solener.2018.09.033

11. ДСТУ Б А.2.2-12 2015. Енергетична ефективність будівель. Метод розрахунку енергоспоживання при опаленні, охолодженні, вентиляції, освітленні та гарячому водопостачанні. [Чинний від 2016-01-01]. Вид. офіц. Київ: Мінрегіон України, 2015. 140 с.

12. Power data access viewer [Electronic resource]. - Access mode: https://power.larc.nasa.gov/dataaccess-viewer/ (last access: 04.03.20) - Title from the screen.

\section{References}

1. Saleh Nasser Al-Saadi. Modeling and simulation of PCM-enhanced façade systems. PhD thesis. Boulder, Colorado, 2014. 472 p.

2. Djordjević A.V., Radosavljević J.M., Vukadinović A.V., Malenović Nikolić J.R., Bogdanović Protić I.S. Estimation of indoor temperature for a passive solar building with a combined passive solar system. Journal of Energy Engineering, 2017, no.143(4), pp. 04017008-1-10. DOI: 10.1061/(ASCE)EY.19437897.0000437.

3. Zhongting Hu, Wei He, Jie Ji, Shengyao Zhang. A review on the application of Trombe wall system in buildings. Renewable and Sustainable Energy Reviews, 2017, vol. 70(C), pp. 976-987. DOI: 10.1016/j.rser.2016.12.003.

4. Gupta N., Tiwari G.N. Review of passive heating/cooling systems of buildings. Energy Science and Engineering, 2016, no. 4(5), pp. 305-333. DOI: 10.1002/ese3.129.

5. Duffie J.A., Beckman W.A. Solar Engineering of Thermal Processes. Hoboken, John Wiley \& Sons, Inc., 2013. 910 p.

6. Balcomb J. D., McFarland R.D. A simple empirical method for estimating the performance of a passive solar heated building of the thermal storage wall type. Proc. of $2^{\text {nd }}$ National Passive Solar Conference. Philadelphia, PA, 1978, 13 p. (Preprint copy). 
7. Strizhak P.A., Morozov M.N. Mathematical simulation of building thermal regime including solar gains. Bulletin of the Tomsk Polytechnic University. Geo Assets Engineering, 2015, Vol.326, no.8, pp. 36-46.

8. Issam A. Modeling of thermal modes of buildings operation using MatLab / Simulink systems. University news. North-Caucasian region. Technical sciences series, 2009, no.1, pp. 95-99.

9. Matuska T. A simple Trombe wall: Comparison of different glazings. Proc. of 3rd ISES Congress Eurosan, Copenhagen, 2000, 6 p. (Preprint copy).

10. Özdenefe M., Atikol U., Rezaei M. Trombe wall size-determination based on economic and thermal comfort viability. Solar Energy, 2018, Vol.174, pp. 359-372. DOI: 10.1016/j.solener.2018.09.033

11. DSTU B A.2.2-12 2015. Enerhetychna efektyvnist' budivel'. Metod rozrakhunku enerhospozhyvannya pry opalenni, okholodzhenni, ventylyatsiyi, osvitlenni ta haryachomu vodopostachanni. [State standard of Ukraine B A.2.2-12 2015. Energy efficiency of buildings. Method of calculating energy consumption for heating, cooling, ventilation, lighting and hot water]. Kyiv, Ministry of Regional Development of Ukraine, 2015. $140 \mathrm{p}$.

12. Power data access viewer. Available at: https://power.larc.nasa.gov/data-access-viewer/ (accessed 04 March 2020). 